Prepared for the U.S. Department of Energy

under Contract DE-AC05-76RL01830

\title{
IDF Sagebrush Habitat Mitigation Project: FY2008 Compensation Area Monitoring Report
}

Robin E. Durham

Michael R. Sackschewsky

September 2008

Pacific Northwest

NATIONAL LABORATORY 


\title{
DISCLAIMER
}

This report was prepared as an account of work sponsored by an agency of the United States Government. Neither the United States Government nor any agency thereof, nor Battelle Memorial Institute, nor any of their employees, makes any warranty, express or implied, or assumes any legal liability or responsibility for the accuracy, completeness, or usefulness of any information, apparatus, product, or process disclosed, or represents that its use would not infringe privately owned rights. Reference herein to any specific commercial product, process, or service by trade name, trademark, manufacturer, or otherwise does not necessarily constitute or imply its endorsement, recommendation, or favoring by the United States Government or any agency thereof, or Battelle Memorial Institute. The views and opinions of authors expressed herein do not necessarily state or reflect those of the United States Government or any agency thereof.

\author{
PACIFIC NORTHWEST NATIONAL LABORATORY \\ operated by \\ BATTELLE \\ for the \\ UNITED STATES DEPARTMENT OF ENERGY \\ under Contract DE-AC05-76RL01830
}

Printed in the United States of America

\author{
Available to DOE and DOE contractors from the \\ Office of Scientific and Technical Information, \\ P.O. Box 62, Oak Ridge, TN 37831-0062; \\ ph: (865) 576-8401 \\ fax: (865) $576-5728$ \\ email: reports@adonis.osti.gov
}

Available to the public from the National Technical Information Service,

U.S. Department of Commerce, 5285 Port Royal Rd., Springfield, VA 22161

ph: (800) 553-6847

fax: (703) 605-6900

email: orders@ntis.fedworld.gov

online ordering: http://www.ntis.gov/ordering.htm 


\section{IDF Sagebrush Habitat Mitigation Project: FY2008 Compensation Area Monitoring Report}

Robin E. Durham

Michael R. Sackschewsky

September 2008

Prepared for

the U.S. Department of Energy

under Contract DE-AC05-76RL01830

Pacific Northwest National Laboratory

Richland, Washington 99352 



\subsection{Introduction}

This document provides a review and status of activities conducted in support of the CH2MHill Hanford Group (CHG) compensatory mitigation implementation plan (MIP) for the Integrated Disposal Facility (IDF) (CHG 2007). It includes time-zero monitoring results for planting activities conducted in December 2007, annual survival monitoring for all planting years, a summary of artificial burrow observations, and recommendations for the successful completion of DOE mitigation commitments for this project.

\subsection{Background}

Development of the IDF site has resulted in the unrectifiable loss of roughly 53 ha (131 ac) of mature sagebrush steppe habitat in the 200-East Area at Hanford. Hanford site biological resource guidelines stipulate compensatory mitigation via habitat replacement for this level and type of disturbance (DOE 2001, 2003). A mitigation action plan (MAP) was prepared to outline the measures necessary to mitigate these ecological resource losses (DOE 2005). In the MAP, DOE committed to a compensation planting of 116,600 Wyoming big sagebrush (Artemisia tridentata ssp wyomingensis) seedlings (DOE 2005). Additional activities included the installation of 22 artificial owl burrows. A MIP was prepared by CHG to define and assign tasks for accomplishing the goals and commitments outlined in the MAP.

An area was selected along Army Loop Road, south of the Environmental Restoration Disposal Facility, for the IDF mitigation site (Figure 1). The 106 ha (261 acre) site was divided into four $400 \mathrm{~m} \mathrm{x}$ $330 \mathrm{~m}$ sections on each side of Army Loop road. These sections were divided into two, $200 \mathrm{~m}$ x $330 \mathrm{~m}$ subsections each. As originally planned, each larger section was to be planted with bare-root plants in one subsection, and with container-grown plants in the other (Figure 2). In February 2007, a total of 68,600 seedlings (42,600 bareroot and 26,000 4-in ${ }^{3}$ container-grown seedlings) were delivered and planted into this site (results and other activities detailed in: Durham and Sackschewsky 2007). This number of seedlings represented a delivery shortfall, and as a result, an additional 48,000 locally-derived seedlings (10-in ${ }^{3}$ container-grown seedlings) were procured for planting in FY2008.

On December 3, 2007, CHG took delivery of 34,240, 10-in ${ }^{3}$ sagebrush seedlings; nearly 14,000 fewer seedlings than expected. Planting started on Tuesday, December 4 and continued through Saturday, December 8. Five (5) subsections (N4-A, N4-B, S3-B, S4-A and S4-B) were planted at a nominal density of 6,850 seedlings per subsection. Subsection N3-A has never been planted. In accordance with the MIP, time-zero monitoring was conducted shortly after planting to provide a project baseline. This activity established permanent monitoring transects to follow seedling survival and establishment, and to verify that accurate planting densities (1100 plants/ha (445/ac)) were achieved as outlined in the MIP. The issue of seedling health arose toward the end of the second planting day after several boxes were opened to find plants of deteriorating quality. This occurred during the planting of subsections N4-A and N4-B. For that reason, an assessment of initial plant health was made during the time-zero mapping phase. Survival monitoring for both planting years was conducted during August 2008. Artificial burrows were surveyed in early September to identify maintenance issues and to assess burrow activity. 


\subsection{Methods}

\subsection{Time-zero Mapping}

Mapping commenced on January 2, 2008, to determine planting densities and establish permanent monitoring transects within each of the five subsections. Metal t-posts were used to permanently mark the beginning and end of each 100-m transect line. Each seedling within 5-m of either side of the belt was mapped by assigning coordinates based on the distance along, and distance from the belt. Those seedlings mapped on the right side of the belt (relative to Army Loop Rd.) were assigned positive distance values along the line. Those seedlings on the left side were given negative distance values. Other baseline measurements included seedling height, and two perpendicular widths. Seedlings were evaluated for quality, specifically in subsections N4-A and N4-B.

Following the methodology used in FY2007, each plant was evaluated for planting quality and grouped into one of eight categories: 1) planted correctly; 2) planted too deep; 3) planted too shallow; 4) plant left with obvious air gaps about the roots and crown; 5) multiple plants in hole; 6) planted too deep with air gaps; 7) planted too deep with multiple plants; and 8) planted too shallow with air gaps.

\subsection{Annual Monitoring}

\subsubsection{Shrub Survival}

All mapped seedlings were revisited during August 2008. As before, measures of seedling height and two widths were recorded. Each plant was then rated according to appearance as healthy (1), marginal $(-1)$, or dead (0). A seedling was considered healthy (1) if its leaves were turgid. Marginal plants were identified as exhibiting 75 percent or more chlorotic foliage, or it was thought the seedling would not survive until the next monitoring year. Plants were considered dead when no live leaves were present on any stem, or when previously mapped seedlings could not be relocated.

\subsubsection{Artificial Burrow Surveys}

A foot survey was conducted in September 2008. Each burrow was inspected to ascertain maintenance issues, if any, and to look for signs of use (prints, casings, etc.). Photos were taken from the north side of each burrow entrance.

\subsection{Results}

\subsection{Time-zero Mapping}

A time-zero monitoring summary of planting density and quality is presented in Table 1. The data are presented relative to the site planting layout both north and south of Army Loop Road.

\subsubsection{Planting Density}

Five (5) monitoring transects were mapped. Four (4) lines (N4-A, N4-B, S3-B, and S4-A) showed planting densities within or near MIP specifications (1010, 1010, 970, and 1070 plants per hectare respectively), and one (1) line (S4-B) fell below (790 plants per hectare). The average planting density across the FY08 planting area was calculated to be 970 plants per hectare. 


\subsubsection{Planting Quality}

Greater than 90 percent of all seedlings monitored $(n=484)$ were categorized as planted correctly. A small percentage of seedlings were observed with shallow plantings (4 percent), deep plantings (2 percent) and plantings with air gaps about the roots and crown (2 percent). These percentages show a marked improvement over the previous planting year (Durham and Sackschewsky 2007).

\subsubsection{Plant Health}

Nearly 14 percent of all seedlings monitored $(n=484)$ were of poor quality. These percentages were highest in subsection N4-A ( $24 \%$ of $n=101$ seedlings) and N4-B ( $35 \%$ of $n=100$ seedlings). No substandard plants were identified in subsection S4-B.

\subsection{Annual Monitoring}

\subsubsection{Time-One FY08 Planting}

Survival totaled 33 percent across the five (5) transect lines (max=50.6 \% [S4-B]; min=4.0\% [N4-B]) (Figure 3). Of those surviving plants $(n=160), 79$ percent were judged to be in healthy condition. Ninety-one percent of the seedlings $(n=65)$ initially ranked as poor quality at time zero, perished before time-one monitoring.

\subsubsection{Time-Two FY07 Planting}

Overall survival (across all lines and seedling types) totaled 11.5 percent (down 7.5\% from FY07). A comparison of bare-root and plugling survival by section and monitoring year is presented in Figure 4. While the overall survival is low for both seedling types, bare-root stock appears to have a consistently higher survival across the sections both initially and over time.

Bare-root survival totaled 13.8 percent (down 7.4\% overall from FY07). Of those surviving bare-root plants ( $\mathrm{n}=71), 89$ percent were considered thriving and some were starting to show signs of flowering. Plugling survival totaled 6.5 percent (down $7.8 \%$ overall from FY07). Of those plants still living ( $\mathrm{n}=15$ ), 100 percent were considered thriving.

\subsection{Artificial Burrows}

Twenty-two burrows were inspected. No signs of use by burrowing owls were observed. All burrows were found with entrances obscured or partially obscured by debris, vegetation, and/or windblown sand.

\subsection{Discussion}

Survival of seedlings planted in FY08 had overall higher survival after the first summer (33\%) than those planted in FY07 (19\% overall). Three of the five sections planted in FY08 had survival rates in the vicinity of 50\%; the two sections with low survival had a higher proportion of sub-standard seedlings. The sub-standard seedlings had essentially zero survival.

The higher initial survival rate of the FY08 planting compared to the FY07 planting is partially attributable to planting at a more favorable time of year (December versus February) and partially to better quality control of the planting process. In FY07, 33\% of the seedlings were improperly planted (Durham and Sackschewsky 2007), whereas in FY08, less than 10\% appeared to be planted improperly. 
Overall survival of the seedlings planted in FY07 after two years was approximately $60 \%$ of the firstyear survival (11.5\% now compared to $19 \%$ after one year). Bare root plants are surviving at about twice the rate of $4-$ in $^{3}$ tublings after two years (13.8\% vs. 6.5\%).

Survival is well below the goal of $60 \%$ defined in the Mitigation Action Plan (DOE 2006). In straight numbers, the MAP goal was to plant 116,000 sagebrush seedlings with an anticipated end result of 69,600 surviving sagebrush plants within the 106 ha mitigation area. To date, about 102,840 plants have been planted, of which 19,000 to 20,000 are likely to be alive.

Additional action will be needed to meet the MAP commitment. This mitigation site may not be the desired location for additional plantings. Even with good planting techniques and good timing, $10-$ in $^{3}$ tubling survival was at best 50 percent in FY08 and in some cases considerably lower. Bare root seedlings showed higher survival rates. It is difficult to judge the potential of bare root stock on this planting site because quality control (by the grower, planting quality, and root pruning during outplanting) was a problem in FY07. Still, bare roots would be the recommended choice if the site along Army Loop Road continues as the IDF sagebrush mitigation area. Bare root stock is innately different than stock grown in a container. Bare roots tend to be hardier, stronger plants, but they are subject to the environment in which they are grown. Field conditions such as low germination in the rows can result in larger than expected plant sizes (as seen in FY07). Root pruning by the grower once during the growing season and again prior to harvesting must be a requirement (this was not done for the FY07 planting). Conducting these activities during out planting will significantly reduce survival in the field. A planting subcontractor experienced with container-grown seedlings will need to understand the implications of using bare root stock (e.g., a planter might be able to carry 25 to 50 bare root plants at a time compared to 125 small pluglings; or it may take two swings of the hoedad compared to one for a plugling).

Thus far, there has been no indication that the artificial burrows have been used by burrowing owls. However, almost all of them now require maintenance, and will not be used unless the openings are cleared of sand and debris.

We recommend that project managers consider alternatives for meeting the remaining mitigation commitments during the fall of FY09. Planning during the winter and spring of FY09 will allow for additional planting to occur in early FY10. Managers should also plan to have the openings of the owl burrows cleaned out prior to March 2009.

\subsection{References}

CH2MHill Hanford Group, Inc. (CHG). 2007. Compensatory Mitigation Implementation Plan for the Integrated Disposal Facility. RPP-29051 Rev. 1.

Durham, R.E., and M.R. Sackschewsky. 2007. Integrated Disposal Facility Sagebrush Habitat Mitigation Project: FY2007 Compensation Area Monitoring Report. PNNL-16976. Pacific Northwest National Laboratory, Richland, WA.

U.S. Department of Energy. 2001. Hanford Site Biological Resource Management Plan. DOE/RL 9632 Rev. 0. U.S. Department of Energy, Richland, WA.

U.S. Department of Energy. 2003. Hanford Site Biological Resource Mitigation Strategy. DOE/RL 9688 Rev. 0. U.S. Department of Energy, Richland, WA.

U.S. Department of Energy. 2006. Mitigation Action Plan for the U.S. Department of Energy, Hanford Site, Integrated Disposal Facility (IDF) Construction. DOE/ORP-2005-5 Rev. 0. 


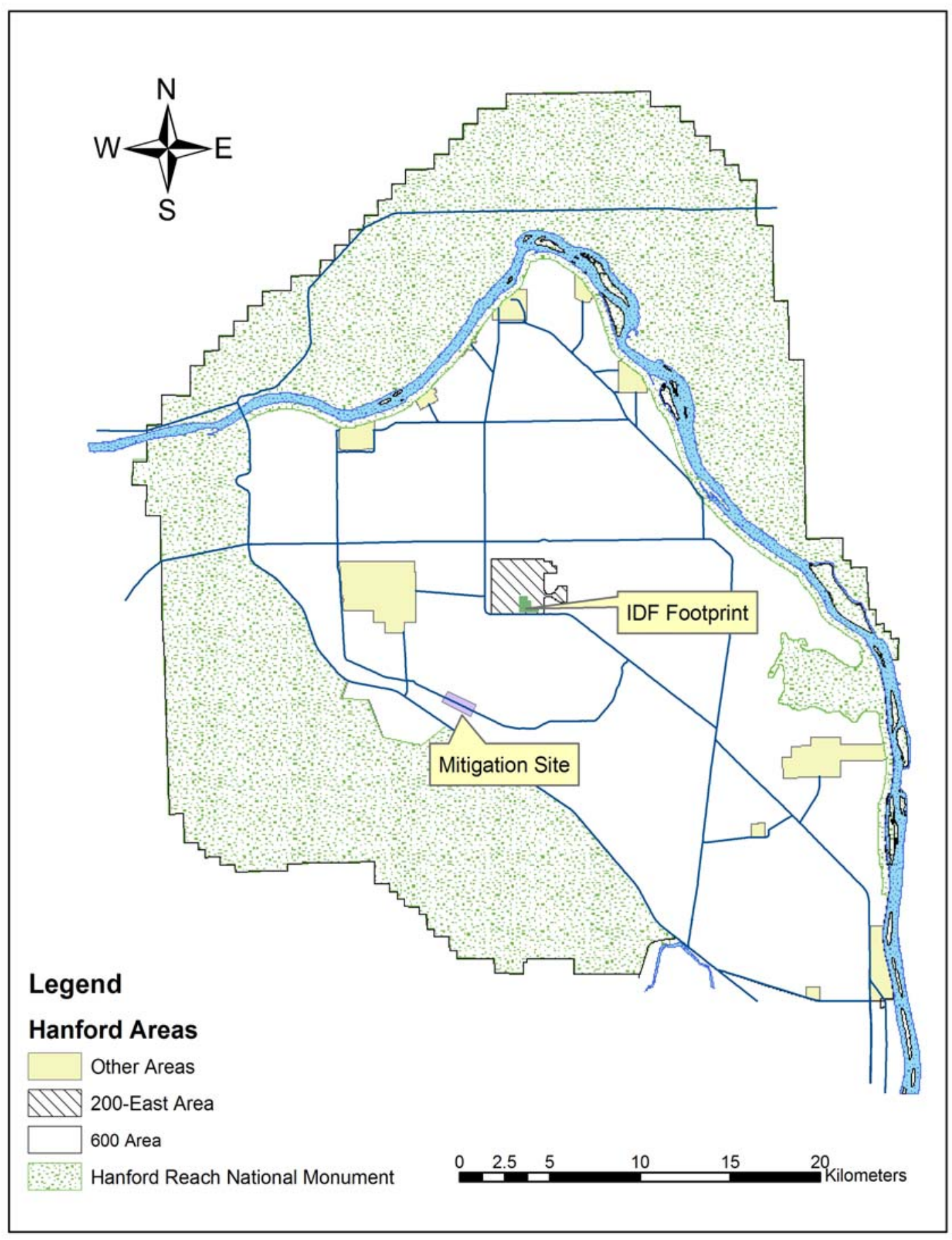

Figure 1. Location of the Integrated Disposal Facility and the Compensatory Mitigation Site 


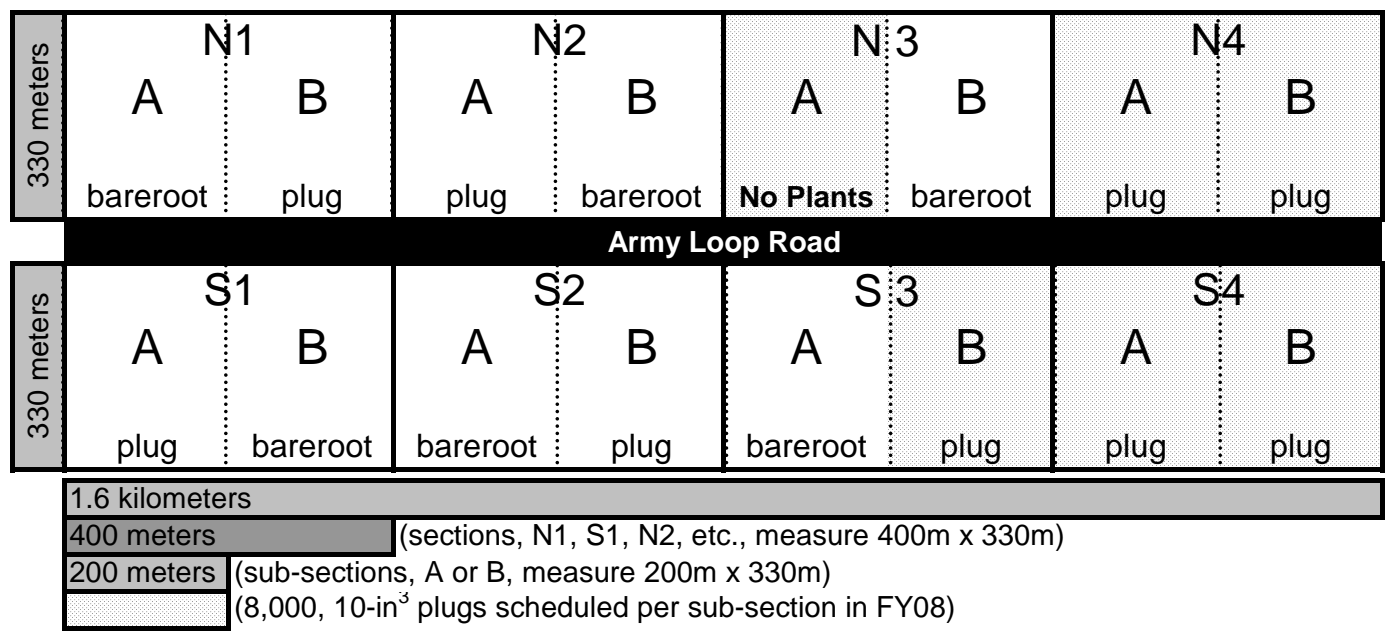

Figure 2. IDF Mitigation Planting Layout: by Section, Subsection, and Seedling Type to be Planted (Not to Scale) 
Table 1. Time-Zero Monitoring Summary - IDF Mitigation Project, FY2008. Data are Presented by Planting Locations as they Appear Both North and South of Army Loop Road by Section, Subsection, Seedling Type, and Planting-Quality Condition*

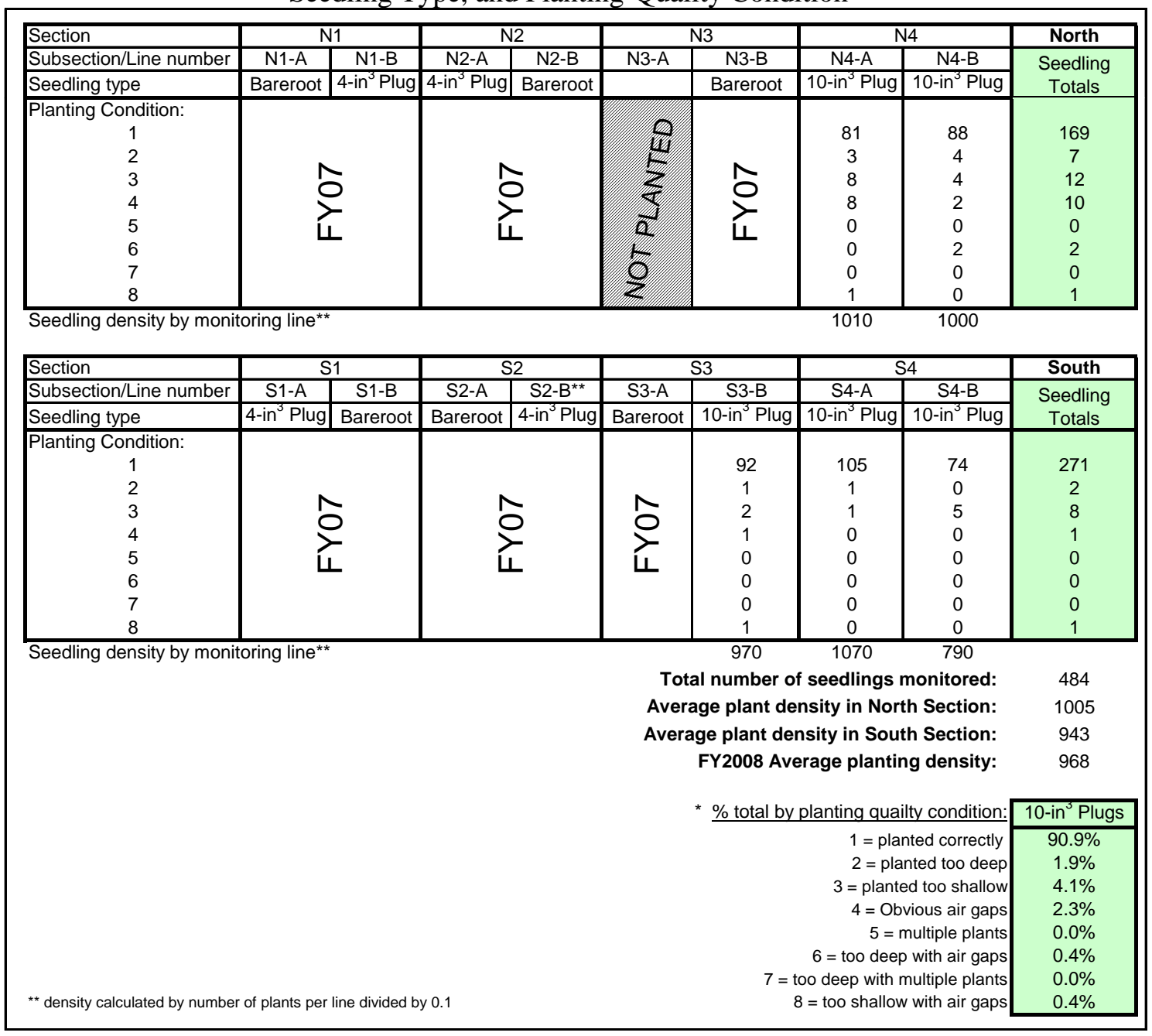




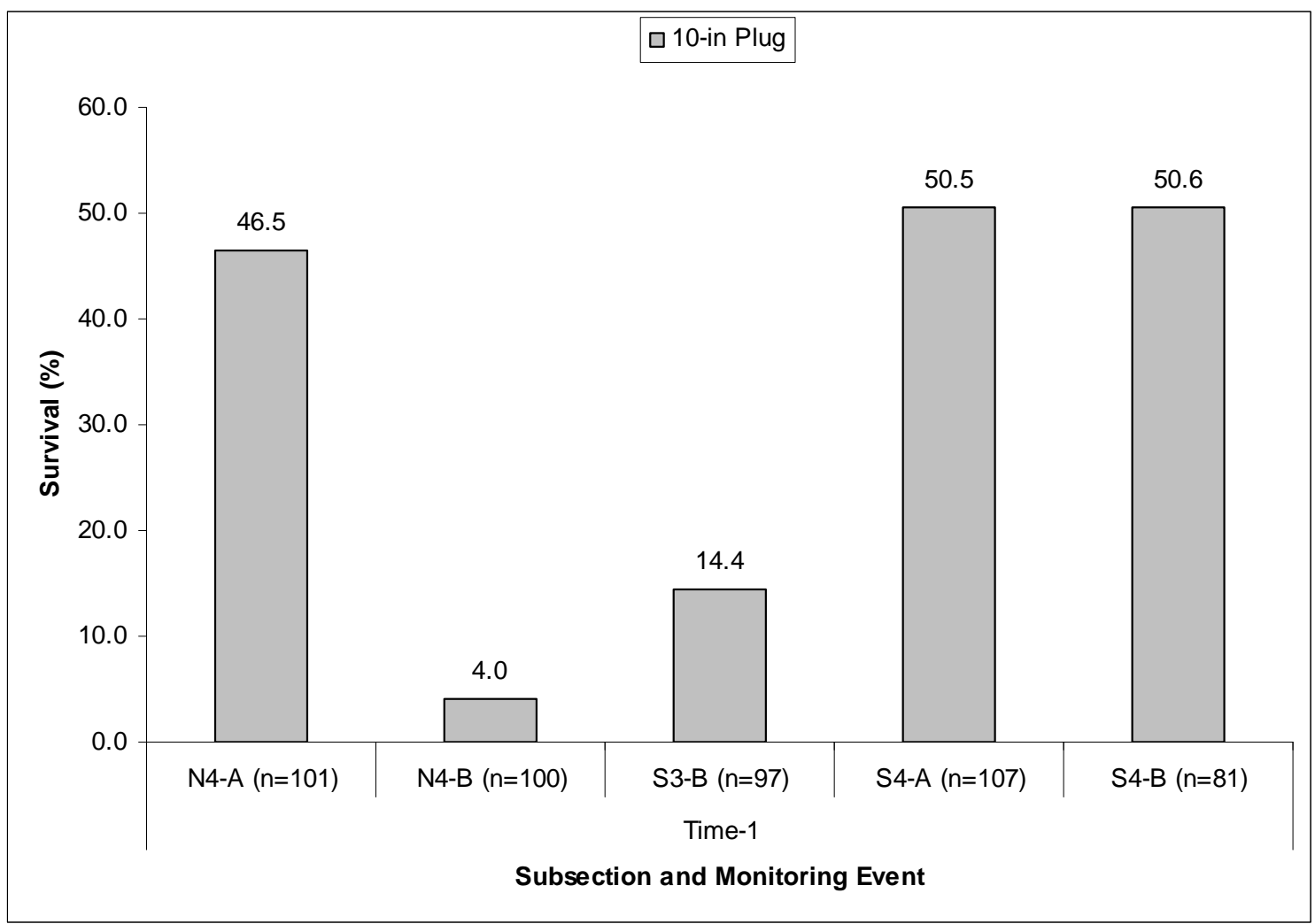

Figure 3. Time-One Survival of the FY2008 IDF Sagebrush Mitigation Planting. Seedling Type: 10-in ${ }^{3}$ container-grown plug 


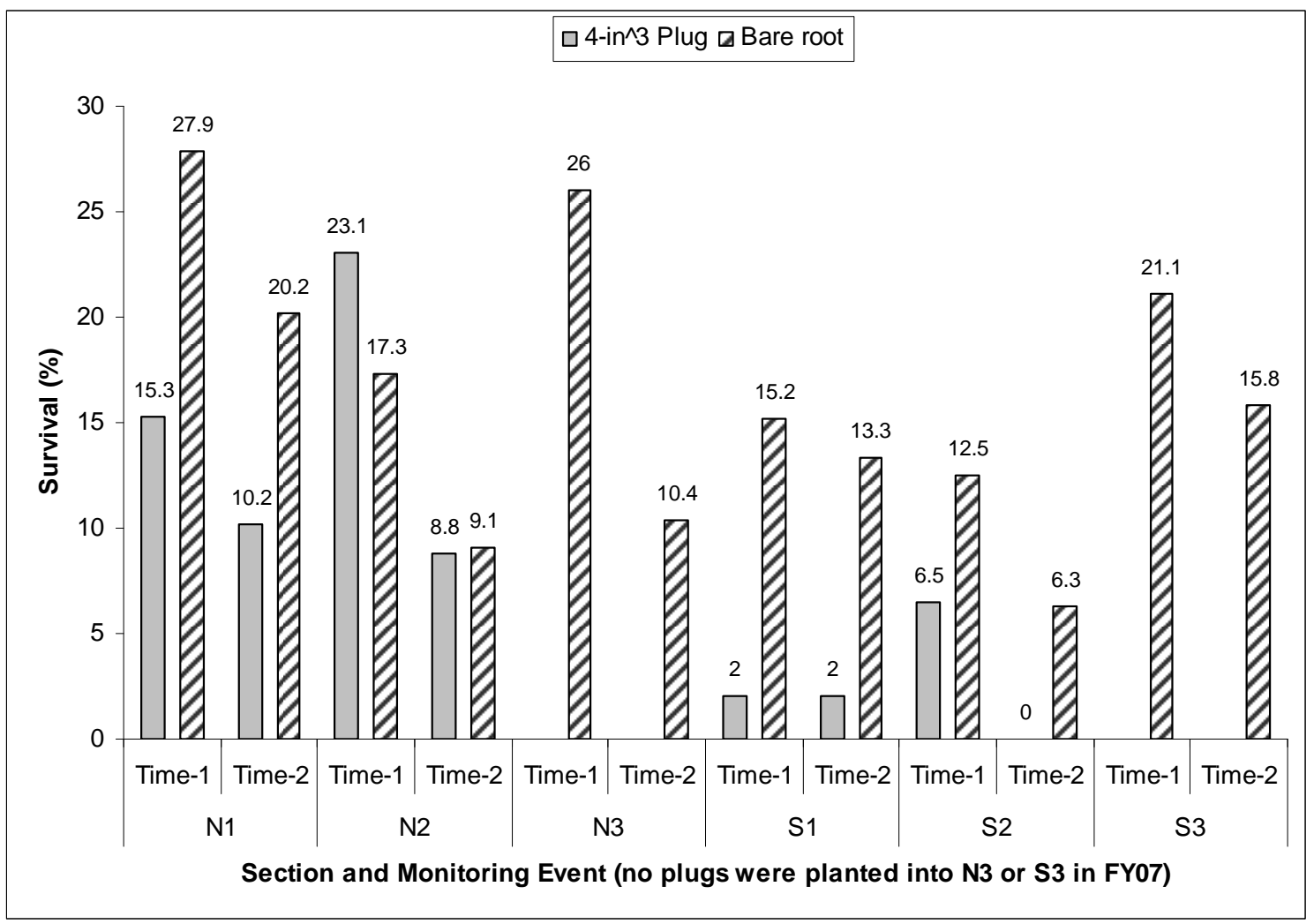

Figure 4. Time-Two Survival Comparison of the FY2007 IDF Sagebrush Mitigation Planting. Data are Presented by Seedling Type (4-in ${ }^{3}$ container-grown plugs vs. bare-root stock), Planting Section and Monitoring Event (Time-1 vs. Time-2) 